\title{
A Rare Side Effect of Entecavir: Hepatomegaly and Steatosis
}

\section{Entekavire Bağlı Nadir Bir Yan Etki: Hepatomegali ve Steatoz}

\author{
Tayibe BAL1, Yusuf ÖNLEN2, Selma ILKAY ŞAHIN2 \\ 1 Siirt State Hospital, Clinic of Infectious Disease and Clinical Microbiology, Siirt, Turkey \\ 2Mustafa Kemal University Faculty of Medicine, Department of Infectious Disease and Clinical Microbiology, Hatay, Turkey
}

\begin{abstract}
Hepatomegaly and steatosis are rare but potentially fatal side-effects of nucleoside analogues. Here, we present the case of development of hepatomegaly and steatosis in a 53-year-old male who had been treated with entecavir for five years. There were no symptoms of lactic acidosis. At three months after changing entecavir to tenofovir, the liver size returned to normal and maintained within the normal range during the 3-year follow-up. Therefore, it can be presumed that the hepatomegaly and steatosis were due to entecavir therapy. There are very few reports of hepatomegaly and steatosis caused by nucleoside analogues and the majority of the reported cases were associated with lactic acidosis. To the best of our knowledge, there are no previously reported cases of hepatomegaly and steatosis due to entecavir therapy without evidence of lactic acidosis. The aim of this clinical report was to point out a rare side-effect of entecavir and to share our treatment approach.

Keywords: Entecavir, hepatomegaly, steatosis
\end{abstract}

\section{öz}

Hepatomegali ve steatoz nükleozid analoglarının nadir görülen ancak fatal seyredebilen bir yan etkisidir. Bu olgu sunumunda 5 yıl süre ile entekavir tedavisi almakta olan 53 yaşında erkek hastada hepatomegali ve steatoz gelişimi sunulmuştur. Hastada entekavir tedavisi sırasında laktik asidoz bulgusu olmaksızın progresif hepatomegali ve steatoz gelişmiştir. Entekavir tedavisi tenofovir ile değiştirildikten 3 ay sonra karaciğer boyutu normalleşmiş ve tenofovir tedavisinin ilk 3 yılında normal aralıkta seyretmiştir. Bu nedenle, hepatomegali ve steatozun entekavir tedavisine bağlı gelişmiş olması muhtemeldir. Nükleozid analoglarının neden olduğu hepatomegali ve steatoz nadirdir ve bildirilen olguların çoğunda laktik asidoz ile ilişkilidir. Bildiğimiz kadarıla daha önce entekavir tedavisine sekonder, laktik asidoz bulgusu olmaksızın gelişen hepatomegali ve steatoz olgusu bildirilmemiștir. Bu olgu sunumunun amacı entekavirin nadir görülen bir yan etkisini ortaya koymak ve uygulanan tedavi yaklaşımını paylaşmaktır.

Anahtar Kelimeler: Entekavir, hepatomegali, steatoz

Bal T, Önlen Y, Illkay Şahin S. A Rare Side Effect of Entecavir: Hepatomegaly and Steatosis. Viral Hepat J. 2017;23:80-82.

\section{Introduction}

Nucleoside/nucleotide analogues (NAs) are considered the first-line treatment for chronic hepatitis $\mathrm{B}(\mathrm{CHB})$ and have been reported to be well tolerated with minor side-effects, even with long-term use (1). Unfortunately, they can also have some rare but serious side-effects. All five NAs carry a black-box warning about the possibility of severe hepatomegaly and steatosis secondary to mitochondrial toxicity in their prescription information on the basis of data from the human immunodeficiency virus (HIV) literature $(2,3)$. However, there have been very few reports of the occurrence of these serious side-effects in CHB patients and all reported cases of hepatomegaly and steatosis have been associated with lactic acidosis and most of the patients had impaired liver function $(4,5,6)$. The case is here reported of a non-cirrhotic CHB patient who developed hepatomegaly and steatosis associated with longterm administration of entecavir monotherapy.

\section{Case}

We report a 53-year-old male non-cirrhotic patient with $\mathrm{CHB}$ who has been treated with entecavir since November 2008. A preliminary ultrasound of the abdomen revealed a normal liver size. After 5 years of treatment (in January 2014), ultrasonography showed $163 \mathrm{~mm}$ hepatomegaly and steatosis. Six months later, the liver size had increased progressively and on the last ultrasonography,

Address for Correspondence: Tayibe Bal MD, Siirt State Hospital, Clinic of Infectious Disease and Clinical Microbiology, Siirt, Turkey Phone: +90 4844248161 E-mail: dr.tayibal@gmail.com ORCID ID: orcid.org/0000-0002-5315-122X Received: 23.11.2017 Accepted: 19.12.2017

${ }^{\odot}$ Copyright 2017 by Viral Hepatitis Society / Viral Hepatitis Journal published by Galenos Publishing House. 
the liver size of the patient was $175 \mathrm{~mm}$ in diameter. He had no symptoms of lactic acidosis such as abdominal pain, shortness of breath, muscle pain or weakness. Physical examination revealed a palpable liver edge $2 \mathrm{~cm}$ below the right costal margin. The patient was mildly overweight with a body mass index (BMI) of 28. The serum aminotransferase, bilirubin, creatinine, thyroid function and blood lipids levels were all within the normal ranges. Moderate fibrosis (stage: 2) and moderate necro-inflammatory activity (histological activity index: 9) were determined on the liver biopsy which had been performed before the initiation of entecavir therapy. There was no history of exposure to any other NAs, alcohol abuse, congestive heart failure or metabolic syndrome. When this side effect was identified, entecavir was changed to tenofovir. After receiving tenofovir therapy for 3 months, abdominal ultrasound showed a normal liver size. Moreover, the size of the liver has been maintained within the normal range throughout 3 years of tenofovir therapy. In addition, there was no significant change in alanine aminotransferase, aspartate aminotransferase or HBV DNA levels, thyroid function tests, lipid profile and BMI during this period (Table 1).

Table 1. Comparison of the variables between time points (before initiation of tenofovir therapy, at 3-month and 3-year of tenofovir therapy)

\begin{tabular}{|l|l|l|l|}
\hline Variable & Baseline & 3 Months & 3 Years \\
\hline BMI, kg/m² & 28 & 28 & 28 \\
\hline ALT level, U/L & 17 & 20 & 25 \\
\hline AST level, U/L & 19 & 22 & 23 \\
\hline Total cholesterol, mmol/L & 197 & 182 & 198 \\
\hline LDL cholesterol, mmol/L & 115.9 & 126 & 117.5 \\
\hline Triglyceride, mmol/L & 188 & 145 & 123 \\
\hline HBV DNA level, IU/mL & $<20$ & $<20$ & $<20$ \\
\hline TSH, IU/mL & 2.25 & 2.23 & 2.06 \\
\hline Free T4, pg/mL & 1.04 & 1 & 1.09 \\
\hline Free T3, pg/mL & 2.85 & 2.48 & 2.89 \\
\hline $\begin{array}{l}\text { BMI: Body mass index, ALT: Alanine aminotransferase, AST: Aspartate } \\
\text { aminotransferase, HBV: Hepatitis B virus, TSH: Thyroid stimulating hormone, } \\
\text { T4: Thyroxine, T3: Triiodothyoxine, LDL: Low-density lipoprotein }\end{array}$ \\
\hline
\end{tabular}

\section{Discussion}

The case here described progressive hepatomegaly and steatosis without evidence of lactic acidosis in a patient undergoing entecavir monotherapy for $\mathrm{CHB}$ infection. There was no evidence to support other etiologies of hepatomegaly and steatosis such as alcohol abuse, congestive heart failure, obesity, metabolic syndrome or hypercholesterolaemia. Moreover, after cessation of entecavir, the liver size returned to normal within 3 months. It can therefore be considered that the hepatic steatosis and hepatomegaly were most likely caused by the entecavir therapy.

There are currently five NAs approved in Turkey for the treatment of $\mathrm{CHB}$; including lamivudine, adefovir dipivoxil, telbivudine, entecavir and tenofovir dipivoxil fumarate. NAs block hepatitis B virus (HBV) replication by inhibiting the HBV polymerase enzyme.
As they can also inhibit human mitochondrial DNA polymerase gamma (which has a structure similar to that of HBV polymerase enzyme), in some cases, they can cause severe mitochondrial toxicity (7). However, there are insufficient data about which risk factors are predisposing to mitochondrial toxicity of NAs. Previous studies have suggested that the presence of cirrhosis and taking a combination therapy with NAs is associated with an increased risk of mitochondrial toxicity $(4,5)$. In contrast, the current case was non-cirrhotic and was taking entecavir monotherapy.

The clinical presentation of mitochondrial toxicity is variable and depends on the target organ that is involved. On the basis of data from previously published studies of HIV-infected patients, NAs-related mitochondrial toxicity may present with lactic acidosis, neuropathy, myopathy, pancreatitis and hepatotoxicity, including severe hepatomegaly and steatosis $(7,8)$. Nevertheless, there have been only a few reports of patients with $\mathrm{CHB}$ infection who have developed at least one of these mitochondrial toxicity forms due to NAs medication. In addition, most of them were taking these drugs as part of combination antiretroviral therapy (ART) for HIV/HBV co-infection $(4,5,9)$. Thus, the question of whether there is any link between the use of NAs and mitochondrial toxicity in HBV-infected patients remains controversial.

The development of NAs-related hepatomegaly and steatosis without the occurrence of lactic acidosis has been reported in HIV-infected patients (10). However, there have been no previously published cases of HBV-infected patients with isolated hepatomegaly and steatosis attributed to the use of NAs. Although, the blood level of the current case was unknown, there were no signs or symptoms of lactic acidosis/hyperlactatemia on presentation. Therefore, decompensated, lactic acidosis was discounted. Even though, the clinical significance of this is unknown, subclinical elevations in lactate level have been described in HIV-infected patients receiving NAs therapy (11). Therefore, the possibility of chronic, compensated, asymptomatic hyperlactatemia cannot be ruled out in the current case.

In prescription information of all five NAs approved for $\mathrm{CHB}$, discontinuation of NAs is recommended in patients who develop this severe side-effect $(2,3)$. This may be because it is not known whether this mild syndrome can change from a mild to a severe form.

According to a literature review of HIV-infected patients with symptoms of mitochondrial toxicity, discontinuation of ART and changing the class of ART regimens after completely resolution of symptoms is recommended (12). Symptoms of mitochondrial toxicity will generally resolve once treatment stopped, although it can also be fatal even after discontinuation of NA (2). However, there are insufficient data to make recommendations about HBVinfected patients. As there were no signs or symptoms of lactic acidosis/hyperlactatemia in the current case, anti-HBV therapy was not terminated. As no treatment option other than NAs is available for the underlying HBV infection and the European Association for the Study of the Liver guidelines recommend the long-term administration of a potent NA for treatment of CHB infection, entecavir was changed to tenofovir, which is another potent alternative agent (13). During a 3-year follow-up, the patient did not show any relapse and the size of the liver has been maintained within the normal range without steatosis. This case highlights 
the importance of considering hepatomegaly and steatosis as side-effects of entecavir therapy. For patients developing these potentially fatal side-effects of entecavir, changing the therapy to tenofovir would appear to be safe. Nevertheless, further long-term experience is required.

\section{Ethics}

Informed Consent: Informed consent form was taken from the patient.

Peer-review: Externally peer-reviewed.

\section{Authorship Contributions}

Surgical and Medical Practices: T.B., Y.Ö., S.I.Ş., Design: T.B., Y.Ö., S.I.Ş., Data Collection or Processing: T.B., Y.Ö., S.I.Ş., Analysis or Interpretation: T.B., Y.Ö., S.I.Ş., Literature Search: T.B., Writing: T.B., Y.Ö., S.I.Ş.

Conflict of Interest: No conflict of interest was declared by the authors.

Financial Disclosure: The authors declared that this study has received no financial support.

\section{References}

1. Ridruejo E, Silva MO. Safety of long-term nucleos(t)ide treatment in chronic hepatitis B. Expert Opin Drug Saf. 2012;11:357-360.

2. Fung J, Seto WK, Lai CL, Yuen MF. Extrahepatic effects of nucleoside and nucleotide analogues in chronic hepatitis $B$ treatment. J Gastroenterol Hepatol. 2014;29:428-434.

3. Entecavir [package insert]. Princeton, NJ: Bristol-Meyers Squibb;2009.
4. Cohen SM, Levy RM, Jovanovich JF, Ahn J. Fatal lactic acidosis associated with the use of combination oral medications to treat reactivation of hepatitis B. J Clin Gastroenterol. 2009;43:10081010.

5. Mao H, Kang T. Lactic Acidosis during Entecavir Antiviral Treatment in a Patient with Hepatitis B Virus-related Decompensated Cirrhosis. West Indian Med J. 2015;64:165-166.

6. Lange CM, Bojunga J, Hoffmann WP, Wunder K, Mihm U, Zeuzem $\mathrm{S}$, Sarrazin C. Severe lactic acidosis during treatment of chronic hepatitis B with entecavir in patients with impaired liver function. Hepatology. 2009;50:2001-2006

7. Kayaaslan B, Guner R. Adverse effects of oral antiviral therapy in chronic hepatitis B. World J Hepatol. 2017;9:227-241.

8. Morris AA, Carr A. HIV nucleoside analogues: new adverse effects on mitochondria? Lancet. 1999;354:1046-1047.

9. Patel V, Hedayati SS. Lactic asidosis in an HIV-infected patients receiving highly active antiretroviral therapy. Nat Clin Pract Nephrol. 2006;2:109-114.

10. ter Hofstede HJ, Koopmans PP, van Haelst UJ. Hepatic steatosis during treatment with zidovudine and lamivudine in an HIVpositive patient. Ned Tijdschr Geneeskd. 1998;142:415-419.

11. John M, Mallal S. Hyperlactatemia syndromes in people with HIV infection. Curr Opin Infect Dis. 2002;15:23-29.

12. Delgado J, Harris M, Tesiorowski A, Montaner JS. Symptomatic elevations of lactic acid and their response to treatment manipulation in human immunodeficiency virus-infected persons: a case series. Clin Infect Dis. 2001;33:2072-2074.

13. EASL 2017 Clinical Practice Guidelines on the management of hepatitis B virus infection. J Hepatol. 2017;67:370-398. 